\title{
Seed germination characteristics of selected native plants of the lower Rio Grande Valley, Texas
}

ROBIN S. VORA

\section{Abstract}

Experiments were conducted to identify treatments that inereased emergence of seeds of 24 woody plant species native to the lower Rio Grande Valley of southern Texas. Sulfuric acid (18.4M $\mathrm{H}_{2} \mathrm{SO}_{4}$ ) scarification significantly increased emergence of huisache (A cacia smallit), hulsachillo (A. schaffneri), Texas ebony (Pithecellobium flexicaule), tenaza (P. pallens), tepeguaje (Leucuena pulverulenta), retama (Parktnsonia aculeata), and western soapberry (Supindus drummondit); treatments such as soaking in distilled water, gibberellic acid ( 0.3 or $1.4 \mathrm{mMol})$, or other scarification techniques were not as effective as acid. Fresh guajillo (A. berlandieri) seeds required no treatment, but 8-month-old seeds had higher emergence with acid scarification. Texas ebony emergence was higher from 10-month-old seed treated with acid than from fresh seeds. No pre-treatment seemed necessary for seeds of coral bean (Erythrina herbacea), Texas persimmon (Diospyros texana), sugarberry (Celtis laevigata), granjeno (C. pallida), pigeon-berry (Rivina humilis), Texas baby-bonnets (Coursetia axillaris), guajillo (A. berlandieri), and lotebush (Ziziphus obtusifolia). Results with blackbrush (A. rigidula), Wright's acacia (A. wrightii), rattlebush (Sesbania drummondii), guayacan (Guaiacum angustifolium), brasil (Condalia hookeri), elbowbush (Forestiera angustifoila), and anacua (Ehretia anacua) seeds were inconclusive. Plants of 16 woody species achieved mean heights of $25 \mathrm{~cm}$ in 45 to 150 days.

Keywords: seed treatments, scarification, brush

Less than 5\% of the lower Rio Grande Valley of Texas remains in native brushland (U.S. Fish and Wildlife Service 1983). These brush communities provide critical habitat for numerous animal species. For this reason, the Texas Parks and Wildlife Department and the U.S. Fish and Wildlife Service are restoring native brush by planting native seeds and seedlings in formerly cultivated fields.

Propagation of native plants requires the development of proper handling methods for seeds and seedlings. Previous research on native plants of the lower Rio Grande Valley has been conducted in laboratory growth chambers, for example, fresh seeds of persimmon (Diospyros texana) germinated best (33 to $90 \%$ ) without any treatment (Plowman and Munson 1983, Everitt 1984). Everitt (1983a) reported germination rates of 87 to $92 \%$ for guayacan (Guaiacum angustifolium) and 66 to $77 \%$ with fresh seed of guajillo (Acacia berlandieri). Many other legume species have hard seed coats, and acid treatments have been used to increase germination of these species. Alaniz and Everitt (1978) obtained best results with Texas ebony (Pithecellobium flexicaule) by soaking seed in concentrated sulfuric acid (hereafter acid) for $\mathbf{3 0}$ to $\mathbf{4 5}$ minutes to get $80 \%$ germination. Maximum germination for huisache (Acacia smallii) was $65 \%$ with acid treatment from 45 to 60 minutes (Scifres 1974). Everitt (1983a, b) obtained $86 \%$ germination by soaking fresh blackbrush (Acacia rigidula) seeds in acid for 20 minutes,

\footnotetext{
Author was forest ecologist at Rio Grande Valley National Wildlife Refuge, Alamo, Texas. His present address is U.S. Forest Service, 1170 4th Avenue South, Park Falls, Wisconsin 54552.

The author thanks $R$. Schumacher for his suggestions on experimental treatments; Z. Labus, R. Flores, V. Pulaski, T. High, and E. Couch for their assistance with greenhouse work; J. Messerly for the analyses of variance tests; and J. Young, J. Everitt, O. Van Auken, Y. Wang, T. Fulbright, F. Bonner, R. Lonard, M. Heep, C. Halvorson, and $\mathrm{N}$. Wells for their editorial suggestions.

Manuscript accepted 8 August 1988.
}

$58 \%$ with 45 minutes acid treatment of huisachillo (Acacia schaffneri) seeds, and $87 \%$ with acid treatment for 15 to 90 minutes of retama (Parkinsonia aculeata) seeds. Similarly, germination of rattlebush (Sesbania drummondii) seeds was improved by soaking in acid for up to 4 hours (Easton 1984). Acid scarification for 60 to 90 minutes followed by cold scarification for 90 days produced best results with western soapberry (Sapindus drummondii) seeds (Munson 1984). Seeds of other species, such as sugarberry (Celtis laevigata), might undergo periods of dormancy that can be broken by prechilling (Bonner 1974, 1984). Fulbright et al. (1986a, b) used a combination of mechanical scarification, gibberellic acid, and heat/chill treatments to obtain $62 \%$ germination of granjeno ( $\mathrm{Ce}$ tis pallida) seeds; and gibberellic acid, moist pre-chilling for 2 weeks, and storage for 8 months as methods of improving germination of anacua (Ehretia anacua) seeds. Alaniz and Everitt (1980) obtained 40 to $60 \%$ germination of anacua seeds by soaking them in acid for 2 hours. The results, however, have not been tested in greenhouse and field structures.

My objective was to develop or improve greenhouse germination techniques for 24 native woody plant species (Table 1). Treatments were based on known germination characteristics for seeds of different taxanomic groups. For example, seeds from families known for hard seed coats, such as Mimosaceae and Fabaceae, were subjected to scarification treatments. A secondary objective was to document the length of time needed for the seedlings to reach $25 \mathrm{~cm}$ in height, which is desired for field planting.

\section{Methods}

Tests were conducted to determine if greenhouse emergence could be increased for these species (Table 1) using the following types of pre-sowing treatments: soaking in distilled water, soaking in gibberellic acid $(0.3$ or $1.4 \mathrm{mMol})$, or in acid $\left(18.4 \mathrm{M} \mathrm{H}_{2} \mathrm{SO}_{4}\right)$, and other scarification techniques such as hot water, sandpaper and rock tumblers. I also tested the combined effects of seed ripeness and acid treatment on Texas ebony emergence. Experiments were done with seeds of various ages.

\section{Seed Collection and Processing}

Seeds were collected from local stands of native brush, primarily the Santa Ana National Wildlife Refuge near Alamo, Texas, between 1984 and 1985 . They were collected directly from plants with the exception of anacua and cedar elm (Ulmus crassifolia), which were swept off the ground. Seeds of leguminous species were extracted manually. Fruits of granjeno, sugarberry, brasil, anacahuita (Cordia boisseri), and elbow bush (Forestiera angustifolia) were depulped for some treatments by rubbing manually against a wire mesh. Western soapberry seeds were removed from shells (pericarps). Seeds were stored in paper sacks on shelves at room temperature until 10 January 1985 and were stored in a refrigerator at $4^{\circ} \mathrm{C}$ after that date.

Experimental Design, Treatments, and Propagation Procedures

A randomized block design was used. Basic treatment types are listed in Table 2. Cedar elm fruits were planted in mulch collected from under the tree. Several unsuccessful exploratory treatments are not described in detail for sake of brevity. With the exception of 
Table 1. Species selected for seed germination experfments.

\begin{tabular}{lll}
\hline \hline Family & Scientific name & Common name \\
\hline Ulmaceae & Celtis pallida & Granjeno \\
& Celtis laevigata & Sugarberry \\
Phytolaccaceae & Rivina hussifolia & Cedar elm \\
Mimosaceac & Acacia rigidula & Pigeon-berry \\
& Acacia berlandieri & Blackbrush \\
& Acacia smallii & Guajillo \\
& Acacia schaffneri & Huisache \\
& Pithecellobium pallens & Huisachillo \\
& Pithecellobium flexicaule & Tenaza \\
& Luecaena pulverulenta & Texas ebony \\
& Acacia wrightii & Wright's acacia \\
& Parkinsonia aculeata & Retama \\
Caesalpinaceac & Erythrina herbacea & Coral bean \\
Fabaceac & Sesbania drummondii & Rattlebush \\
& Coursetia axillaris & Texas baby-bonnets \\
& Guaiacum angustifolium & Guayacan \\
Zygophyllaceac & Sapindus drummondii & Western soapberry \\
Sapindaceae & Condalia hookeri & Brasil \\
Rhamnaceae & Ziziphus obtusifolia & Lotebush \\
& Diospyros texana & Texas persimmon \\
Ebenaceae & Forestiera angustifolia & Elbowbush \\
Oleaceac & Cordia boisseri & Anacahuita \\
Boraginaceac & Ehretia anacua & Anacua \\
& & \\
\hline
\end{tabular}

granjeno, additional treatments were not tried if emergence exceeded $75 \%$ with no treatment. Emergence counts were made once or twice weekly.

In 1985, three replications of each treatment were located randomly in seedling trays (blocks) filled to $4 \mathrm{~cm}$ with a commercial potting mix which consisted of $85 \%$ peat moss and $15 \%$ vermiculite. There were 50 seeds in each replication. When seedlings were 1 to $10 \mathrm{~cm}$ tall, they were transplanted into a 3.8 by 3.8 by $25-\mathrm{cm}$ cardboard tube filled with the same potting mix. Light intensity over the planting trays was $170 \mu \mathrm{molm}^{-2} \mathrm{~s}^{-1}$ (PAR) at $1530 \mathrm{hr}$ on 27 June 1985 ( $10 \%$ of external conditions). The seedlings were transplanted to an area with light intensity of $450 \mu \mathrm{molm}^{-2} \mathrm{~s}^{-1}(27 \%$ of external). Seedling height was measured weekly in 1985 and also

Table 2. Basic treatments.

1. No treatment.

2. Soaking in distilled water 3 to 7 hours or 47 to 49 hours.

3. Soaking in $100 \mathrm{mg} / 1$ or $500 \mathrm{mg} / 1$ gibberellic acid for 3 to 7 hours or 47 to 49 hours with an aerator.

4. Soaking in acid ( $\left.18.4 \mathrm{M} \mathrm{H} \mathrm{H}_{2} \mathrm{SO}_{4}\right)$ for 1 to 120 minutes.

5. Soaking in acid ( $18.4 \mathrm{M} \mathrm{H}_{2} \mathrm{SO}_{4}$ ) for 1 to 120 minutes followed by soaking in distilled water 3 to 7 hours.

6. Other scarification methods such as rubbing lightly with coarse sandpaper for 2 minutes, placing in boiling water and letting cool 5 to 6 hours (or 47 to 49 hours), or placing seeds in a tumbler with crushed rock for 1 to 60 minutes.

weekly in 1986 for seedlings of granjeno, huisache, huisachillo, and western soapberry until mean heights were 20 to $30 \mathrm{~cm}$.

Based on results in 1985, calculations of minimum sample size for $\alpha=0.5$ and $\beta=0.20$ (Kirk 1982) suggested that 5 to 10 replications of each treatment would be necessary. In 1986, therefore, procedures were changed so that there were 8 replications of each treatment, and each replication placed on a separate table (block) in the greenhouse. There were 32 seeds in each replication. Seeds were sown directly into the cardboard tubes, one seed per tube, and the same potting mix used. A 75\% shade cloth over the exterior of one portion of the greenhouse was replaced with a $50 \%$ shade cloth; light intensity varied at each table, and ranged from about $300 \mu \mathrm{molm}^{-2} \mathrm{~s}^{-1}$ (18\% of external) to $600 \mu \mathrm{molm}^{-2} \mathrm{~s}^{-1}$ (36\% of external at mid-afternoon during several measurements in June 1986.

During both years, the plants were watered once every other day for 5 minutes with overhead spray stick sprinklers. Sodium and calcium concentrations in samples of the water supply (March 1985, July and August 1986) varied from 265 to $281 \mathrm{mg} / 1$, and 45 to $97 \mathrm{mg} / 1$, respectively, with total salts estimated at 1,128 to 1,289 $\mathrm{mg} / \mathrm{l}$. Two grams of slow-release fertilizer $(18-7-10+1 \% \mathrm{Fe})$ were placed on the soil surface when seedlings were about $5 \mathrm{~cm}$ tall.

\section{Data Analyses}

Analyses of variance (ANOVA) and Tukey's HSD multiple comparison tests were used to identify significantly different $(P \leq 0.05)$ treatment means, unless emergence was highest under no treatment. Multiple comparison tests were not used to compare graded levels of acid treatment (Petersen 1977).

\section{Results}

\section{Germination of Families \\ Ulmaceae}

Highest emergence of sugarberry occurred with pretreatment of depulped seeds (Table 3). With granjeno, emergence was higher if the pulp was not removed (Table 3). There was no enhancement of emergence from soaking seeds of these 2 species in $1.4 \mathrm{mMol}$ gibberellic acid for 5 hours.

Emergence rates of cedar elm were low $(<10 \%)$. Planting seeds in mulch from under the tree significantly $(P \leq 0.05)$ increased emergence from 3 to $9 \%$.

\section{Phytolaccaceae}

Emergence from 5-month-old pigeon-berry (Rivina humilis) seed planted in May 1985 was $79 \%$ after 43 days. No pregermination treatment of seeds was necessary. No emergence was obtained from 3-year-old seeds.

\section{Mimosaceae}

Scarification of Texas ebony seeds increased emergence (Tables 3 and 4). Emergence was $78 \%$ after acid treatment for 60 minutes. The best alternative scarification method was with crushed rock for 5 minutes ( $29 \%$ emergence). It was superior $(P \leq 0.05)$ to boiling water $(3 \%)$ or placing in water in an oven at $38^{\circ} \mathrm{C}$ for 6 hours $(6 \%)$. Emergence was higher $(P \leq 0.05)$ for 10 -month-old Texas ebony seed that had been soaked in acid for 30 minutes ( $88 \%$ ) than for seeds from green pods, either with or without scarification (48\% and $35 \%$, respectively) (Table 5).

Emergence was similar among treatments for 10-month-old seed of tenaza (Pithecellobium pallens) (Table 3). Seed from the same collection planted a year later had $45 \%$ emergence with acid treatment for 10 minutes, but no emergence without treatment; the threshold for acid treatment was about 5 minutes (Table 4).

Scarification of the seed coat improved emergence of several Acacia species. Huisache and huisachillo seeds both required scarification (Table 3), and highest emergence (97 and $73 \%$, respectively) was with 120 minutes of acid treatment for both species. The threshold for acid scarification was 60 minutes for huisache. Scarification in acid ( 1 minute) or by sandpaper ( 2 minutes) doubled emergence of 8-month-old seeds of Wright's acacia (Acacia wrightii) (Table 3). No scarification was needed with fresh guajillo seeds, while those planted 7 months after collection had higher emergence with 1 minute of acid treatment (Table 3). Treating seed of blackbrush with acid for $\mathbf{1 5}$ minutes followed by soaking in distilled water for 5 hours produced 33\% emergence, similar to emergence (24\%) without treatment (Table 3).

Tepeguaje seeds also required scarification for optimum results 
Table 3. Emerzence (\%) in repponse to pre-sowing treatments.

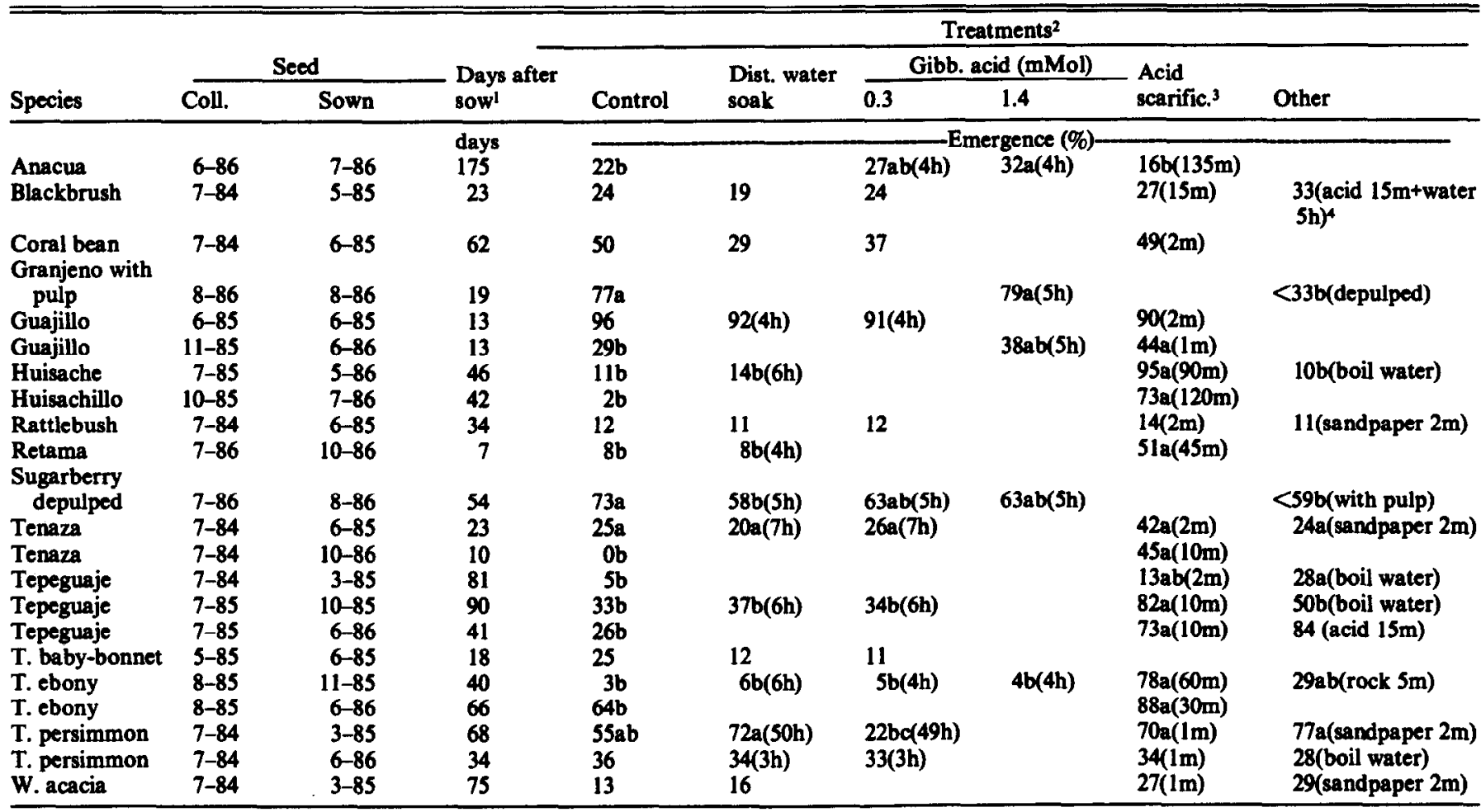

'Number of days after sowing that cumulative emergence data are presented.

$2 \mathrm{~h}=$ hours; $m=$ minutes; treatment means followed by the same letter (within row) were not significantly different $(P>0.05)$.

${ }^{3}$ Emergence less when followed by soaking in distilled water, except blackbrush as noted.

Alackbrush seeds rubbed lightly with coarse sand paper for 2 minutes had $25 \%$ emergence.

Table 4. Emergence (\%) in response to pre-sowing acld $\left(18.4 \mathrm{M}\left(\mathrm{H}_{2} \mathrm{SO}_{3}\right)\right.$ treatment of seeds.

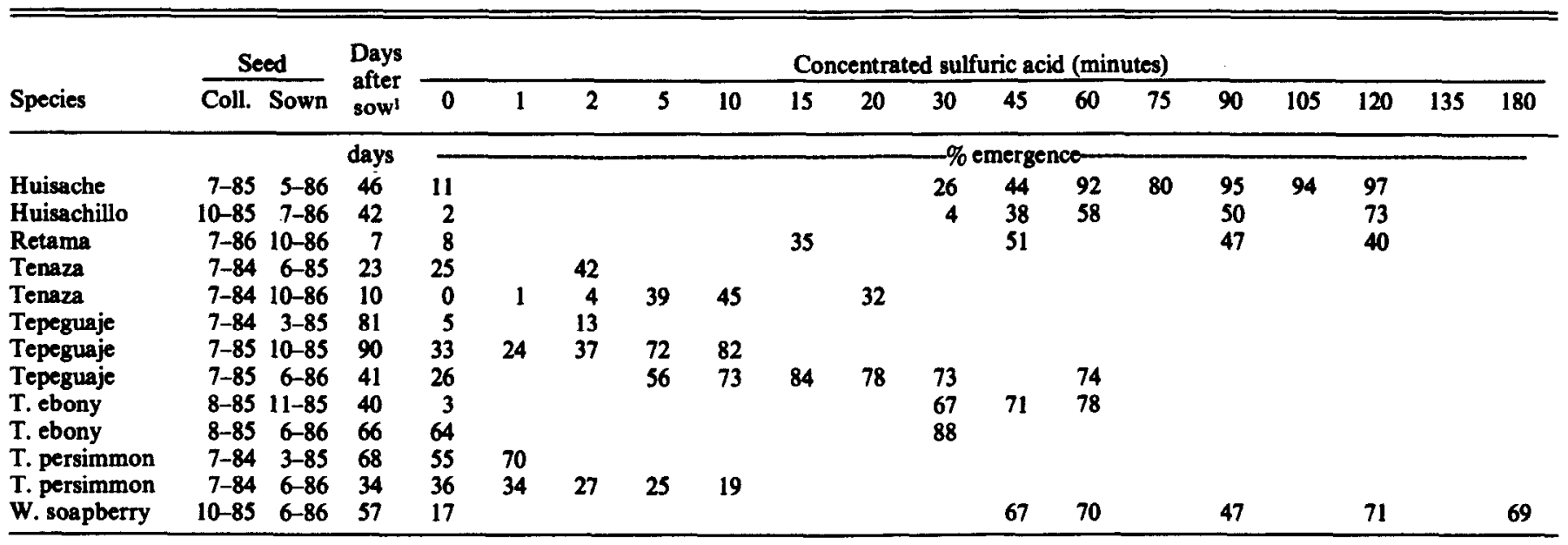

Number of days after sowing that cumulative emergence data are presented.

(Table 3). Soaking 9-month-old tepeguaje (Luecaena pulverulenta) seeds in water brought to boiling temperature and cooled for 48 hours, increased emergence from $5 \%$ for the control to $28 \%$. In a subsequent experiment, soaking 3-month-old seeds in acid for 10 minutes increased emergence from $33 \%$ for the control to $82 \%$. This treatment produced better results than boiling water or 2 minutes in acid $(P \leq 0.01)$ (Tables 3,4$)$. In a later experiment with 11 -month-old seeds, best results were with acid treatment for 15 minutes (Table 4).

\section{Caesalpinaceae}

Emergence of retama seedlings was higher $(P \leq 0.05)$ with acid treatment of 45 minutes ( $51 \%$ instead of $8 \%$ for the control) (Tables 3 and 4).

\section{Fabaceae}

Acid scarification did not significantly $(P \leq 0.05)$ increase emergence of seeds tested of this legume family. Emergence from untreated seed was $25 \%$ for Texas baby-bonnets (Coursetta axilla- 
Table 5. Effect of reed-ripeness and acid treatment on Texas ebony emergence.

\begin{tabular}{lllc}
\hline \hline Seed age & Pod color & Treatment & Mean emergencel \\
\hline & & & $\%$ \\
10 months & Brown & Acid 30 min & 88 \\
10 months & Brown & No treatment & 64 \\
$<1$ month & Green & No treatment & 48 \\
$<1$ month & Green & Acid 30 min & 35
\end{tabular}

'Treatment means were all significantly different $(P<0.05)$ from other treatment means.

ris), $12 \%$ for rattlebush, and $50 \%$ for coral bean (Erythrina herbacea) (Table 3).

\section{Zygophyllaceae}

Soaking 10-month-old seeds of guayacan in distilled water for 3.5 hours produced twice the number of seedlings compared to untreated seeds. Emergence was low (6 to 12\%). Emergence was $34 \%$ with 250 untreated 2-month-old seed planted in September 1986.

\section{Sapindaceae}

Acid scarification for 45 minutes or more significantly ( $P \leq 0.05)$ increased emergence of western soapberry (Table 4). Highest emergence (71\%) was with acid scarification for 120 minutes. Cold stratification for 90 days (Munson 1984) did not increase emergence (e.g., 60 minutes acid-70\%, with pre-stratification-57\%).

\section{Rhamanaceae}

Mean emergence was $95 \%$ in 3 trials with fresh, depulped seed of lotebush (Ziziphus obtusifolia). Results were poor (emergence $<6 \%$ ) with 8-month-old seed of brasil.

\section{Oleaceae}

Results were also poor (emergence $<5 \%$ ) with 8-month-old seed of elbowbush. Emergence was 1 to $3 \%$ better with whole fruit than depulped seeds. A few thousand untreated seeds of elbowbush from the same collection were scattered on a mist table ( $1 / 2$ peat moss, $1 / 2$ perlite) in late June 1985 (not part of an experiment); hundreds of seedlings emerged in September and October.

\section{Ebenaceae}

Emergence obtained with 10-month-old seeds of Texas persimmon that had been scarified with coarse sandpaper for 2 minutes was $77 \%$ compared to $55 \%$ for the control (Table 3). Emergence was highest (36\%) with no treatment in a second experiment 14 months later with seed from the same collection (Table 3). Emergence decreased with increasing length of acid treatment (Table 4).

\section{Boraginaceae}

Anacua seeds soaked in $1.4 \mathrm{mMol}$ gibberellic acid had highest emergence (Table 3). Anacahuita seeds that were 11 months of age produced 21 plants from 30 seeds.

\section{Seedling Height Growth}

Seedling height growth was variable (Table 6). Seedlings generally required 45 to 150 days to achieve $25 \mathrm{~cm}$ height. Some species such as guajillo, tenaza, and rattlebush had fast initial growth. Rattlebush continued with rapid growth, reaching $25 \mathrm{~cm}$ in 45 days, and eventually $2.5 \mathrm{~m}$. Other species, such as tepeguaje, increased growth dramatically once daytime temperatures stayed above $30^{\circ} \mathrm{C}$ (photoperiod also increased). Other plants, such as Texas baby-bonnets, guayacan, and Texas persimmon grew slowly. Height growth measurements indicated that most seeds need to be sown in the greenhouse at least 90 days, and in some cases 150 days, before field planting.
Table 6. Time (days) till mean seedling heisht of 5,10 and $25 \mathrm{~cm}^{1}$ for 16 species (- indicates not measured).

\begin{tabular}{llccc}
\hline \hline & Date & \multicolumn{3}{c}{ Height (cm) } \\
\cline { 2 - 5 } Species & planted & 5 & 10 & 25 \\
\hline & & & days- & \\
Blackbrush & Jun 85 & 40 & 50 & 110 \\
Coral bean & Jun 85 & - & 18 & 73 \\
Granjeno & Aug 86 & - & - & 70 \\
Guajillo & Jun 85 & 8 & 18 & 90 \\
Guayacan & May 85 & 70 & - & - \\
Huisache & May 86 & - & - & 52 \\
Huisachillo & Jul 86 & - & - & 80 \\
Rattlebush & Jun 85 & - & 20 & 45 \\
Sugarberry & Jun 85 & 27 & - & $70^{2}$ \\
Tenaza & Jun 85 & 15 & 50 & 90 \\
Tepeguaje & Mar 85 & 45 & 60 & 80 \\
T. baby bonnets & Jun 85 & 25 & 40 & 150 \\
Texas ebony & Aug 85 & - & - & 90 \\
T. persimmon & Mar 85 & 80 & 100 & 150 \\
W. soapberry & Jun 86 & - & - & 80 \\
Wright's acacia & Mar 85 & 18 & 40 & 70 \\
\hline
\end{tabular}

'Estimated by interpolation because seedling heights were not measured daily.

2 Seeds sown in August 1986 produced plants with mean height of $40 \mathrm{~cm}$ in 77 days.

\section{Discussion}

No treatment seemed necessary for fresh seeds of sugarberry (depulped), granjeno (whole fruit), lotebush (depulped), pigeonberry (whole fruit), or 10-month-old coral bean seeds. The first 4 drupe-producing species are thought to be some of the most important wildlife food plants. Results with depulped granjeno seeds (33\% emergence) were similar to those obtained by Fulbright et al. (1986b). Retaining the pulp when planting fresh granjeno seeds appears to be beneficial, and the complex set of pre-sowing treatments recommended by Fulbright et al. (1986b) unnecessary.

Leguminous species, especially of the family Mimosaceae, required scarification for high emergence rates. These included Texas ebony, tenaza, huisache, huisachillo, Wright's acacia, tepeguaje, and retama. Hard seed coats seem to be the major impediment to rapid germination. I obtained higher emergence with soaking seeds in acid for longer periods than recommended previously for 3 of these species. Alaniz and Everitt (1978) obtained maximum germination (80\%) for Texas ebony after soaking seeds in acid for $\mathbf{3 0}$ to 45 minutes. Emergence increased up to $78 \%$ after 90 minutes soaking in my experiment, the longest period I tried with that species (Table 4). Similarly, with huisache Scifres (1974) obtained highest germination after $\mathbf{4 5}$ to 60 minutes of acid soaking, and with huisachillo Everitt (1983b) had best results after 45 minutes of this treatment, while emergence continued to increase up to 120 minutes in my experiments with these species, the longest period evaluated (Table 4). Results with retama were similar to those of Everitt (1983b).

Nokes (1986) suggested that early harvest of seeds that were mature, but had not completely hardened their seed coats, might be a way of avoiding scarification treatment. This was not advantageous with Texas ebony because emergence was higher with 10month-old acid-scarified seeds (Table 5). Nokes also noted that immature seeds often produced weak and spindly seedlings or failed to germinate altogether.

Results of seed scarification and soaking in water were mixed with other legumes. Age of the seed (10 months) may have been a reason for low emergence of blackbrush and rattlebush in my experiments. I did not obtain significantly higher emergence of blackbrush with 15 minutes of acid treatment as Everitt (1983a) had with fresh seed of that species. Acid treatment for 2 minutes did not improve emergence of rattlebush (Table 4), but a much 
lengthier soak of 4 hours recommended by Easton (1984) was not evaluated. Results with fresh guajillo seeds were similar to those of Everitt (1983a) (no treatment was necessary), but acid treatment for 1 minute increased emergence $(P \leq 0.05)$ of 5 -month-old seed. This suggested that the seed coat of guajillo might harden with time. Emergence of Texas baby bonnets was low (25\%) and further experimentation is needed with that species, especially since it is considered a rare plant (Lonard et al. 1989).

Everitt (1984) stated that fresh seeds of Texas persimmon germinated well without treatment, and viability was not reduced after storage under room conditions for 2 years. Mild scarification and soaking in distilled water had positive effects on emergence of 8-month-old seeds, and no treatment was necessary with 23month-old seeds (Tables 3 and 4). Emergence of untreated seeds dropped by $35 \%$ over that period suggesting loss of viability.

Low emergence was obtained for cedar elm, guayacan, anacua, brasil, and elbowbush, and further experimentation is needed with these species. Emergence results with guayacan and anacua were much lower than that obtained in some laboratory germination tests (Alaniz and Everitt 1980, Everitt 1983a). Fulbright et al. (1986a) did not obtain superior germination of anacua seeds with acid scarification as did Alaniz and Everitt (1980), and plant growers have reported mixed results (pers. commun.). Anacua, brasil, and elbowbush seem to have complex dormancy mechanisms that need to be identified. Cedar elm seeds appear to have very low viability, and time of collection and sowing are probably important.

Many growers have reported trouble growing anacahuita (pers. commun.). My results with depulped 11-month old seed were good (70\%), although the sample size of 30 was small. Anacahuita seeds might have immature embryos when the fruits first drop and may require a long period of after-ripening before germination can occur.

Several species, such as lotebush, might germinate readily at seed drop, but if stored or if conditions are otherwise unfavorable, may undergo dormancy for an extended period. Other researchers (J. Everitt, pers. commun.) have had low success growing lotebush from stored seed. Seed viability may also differ considerably from plant to plant with some of these species.

The salinity of the water in the greenhouse was a concern because salts can stunt seedling growth (Everitt et al. 1977, Salisbury and Ross 1985). Laboratory experiments, however, indicate many plants of the Lower Rio Grande Valley have high tolerances of salts before germination is reduced significantly, varying from $2,000 \mathrm{mg} / 1$ for guajillo to more than $10,000 \mathrm{mg} / 1$ for blackbrush (Everitt 1983a). Salts might accumulate to toxic levels if plants are stored in the greenhouse for long periods without flushing by rain.

In general, highest emergence was achieved with fresh, mature seeds. With 8 - to 10 -month-old seeds, $50 \%$ and better emergence was obtained with Texas ebony, huisache, huisachillo, tepeguaje, coral bean, western soapberry, Texas persimmon, and anacahuita. Storage techniques must be developed for other species if seeds are to be collected in the summer and not planted in fields until fall and winter during cooler and wetter conditions.

\section{Literature Cited}

Alaniz, M.A., and J.H. Everitt. 1978. Germination of Texas ebony seeds. J. Rio Grande Valley Hortic. Soc. 32:95-100.

Alaniz, M.A., and J.H. Everitt. 1980. Germination of anacua seeds. J. Rio Grande Valley Hortic. Soc. 34:75-80.

Bonner, F.T. 1974. Celtis L. Hackberry. p. 411-416. In: Seeds of woody plants in the United States. USDA Agr. Handb. No. 450. Washington, D.C.

Bonner, F.T. 1984. Germination test for sugarberry (Celtis laevigata Willd.). Newsletter Assoc. Official Seed Analysts 58:24-26.

Eeston, E.F. 1984. Drummond rattlebox (Sesbania drummondii) germination as influencd by scarification, temperature, and seeding depth. Weed Sci. 32:223-225.

Everitt, J.H. 1983a. Seed germination characteristics of 3 woody plant species from south Texas. J. Range Manage. 36:246-249.

Everitt, J.H. 1983b. Seed germination characteristics of 2 woody legumes (retama and twisted acacia) from south Texas. J. Range Manage. 36:411-414.

Everitt, J.H. 1984. Germination of Texas persimmon seed. J. Range Manage. 36:411-414.

Everitt, J.H., A.H. Gerbermann, and J.A. Cuellar. 1977. Distinguishing saline from non-saline rangelands with skylab imagery. Photogrammetric Engineering and Remote Sensing 43:1041-1047.

Fulbright, T.E., K.S. Flenniken, and G.L. Waggerman. 1986a. Methods of enhancing germination of anacua seeds. J. Range Manage. 39:450-453.

Fulbright, T.E., K.S Flenniken, and G.L. Wagkerman. 1986b. Enhancing germination by spiny hackberry seeds. J. Range Manage. 39:552-554.

Kirk, R.E. 1982. Experimental design: Procedures for the behavioral sciences. 2 ed. Brooks/Cole Publ. Co.

Lonard, R.I., J.H. Everitt, and F.W. Judd. 1989. Woody Plants of the Lower Rio Grande Valley, Texas. N.A. Browne, illustrator. Texas Memorial Museum Press, Austin, Tex. (In press).

Martin, R.E., R.L. Miller, and C.T. Cushwa. 1975. Germination respondes of legume seeds subjected to moist and dry heat. Ecology 56:1441-1445.

Munson, R.H. 1984. Germination of western soapberry as affected by scarification and stratification. HortScience 19:712-713.

Nokes, J. 1986. How to grow native plants of Texas and the Southwest. Texas Monthly Press, Austin, Texas.

Petersen, R.G. 1977. Use and misuse of multiple comparison procedures. Agron. J. 69:205-208.

Plowman, R.D., and R.H. Munson. 1983. Seed dormancy in Texas persimmon (Diospyros texana Scheele). Plant Propagator 29:14-15.

Salisbury, F.B., and C.W. Ross. 1985. Plant physiology. 3rd edition. Wadsworth Publ. Co., Inc., Belmont, Calif.

Scifres, C.J. 1974. Salient aspects of huisache seed germination. Southwest. Natur. 18:383-392.

U.S. Fish and Wildlife Service. 1983. Land protection plan: Lower Rio Grande Valley National Wildlife Refuge. U.S. Fish \& Wildlife Serv., Albuquerque, N. Mex. 